many, the main importance of Aspergillus is as a source of toxins - aflatoxins and others. Several contributors cover the chemistry and biosynthesis of the toxins and their various impacts on agriculture. Aspergillus is also industrially important, and the volume also includes accounts of its use in production of organic acids and extracellular enzymes and in fermentations used in the food industry. Some attention is also given to Aspergillus as an occasional human pathogen. This conference book is likely to be more useful and less ephemeral than most in that it brings together information that is otherwise rather widely dispersed.

J. R. S. Fincham is in the Division of Biological Sciences, University of Edinburgh, Kings Buildings, West Mains Road, Edinburgh EH9 3JG, UK.

\section{Green business}

\section{David Pearce}

The Ecology of Commerce: How Business Can Save The Planet. By Paul Hawken. Weidenfeld and Nicolson: 1993. Pp. 250. $£ 17.99$.

A SURE sign that an idea has come of age is when it is borrowed, repackaged and sold as new. In The Ecology of Commerce Paul Hawken has done exactly that. The message is that we do not pay the full cost of production of the goods and services we buy. Those goods and services use up scarce environmental resources - the global atmosphere, the oceans, the air we breathe, the landscapes we admire - but usually only part, and often none, of those environmental costs is reflected in the price in the market-place. By treating the environment as a free good, we have degraded it, only to find that it is not free after all and that we are suffering from this fundamental economic folly. The answer then is to put the value of environmental resources into production costs and market prices. The mechanisms for doing this are many and varied. Pollution taxes and charges are one way. Pollution permits that can be traded in special markets are another. Deposit-refund systems (the old 'penny on a bottle') are yet another. The more polluting the product the more it will cost, sending a signal to producers to switch to cleaner technology, and to consumers to switch to cleaner products. Then, and only then, can it be left to the market-place to settle what and how much gets produced.

If it sounds familiar, it is. Hawken acknowledges his intellectual debt to Arthur Pigou who held the chair of political economy in Cambridge, England, for 35 years from 1908 (though, curiously, he re-christens him Nicholas Pigou). What

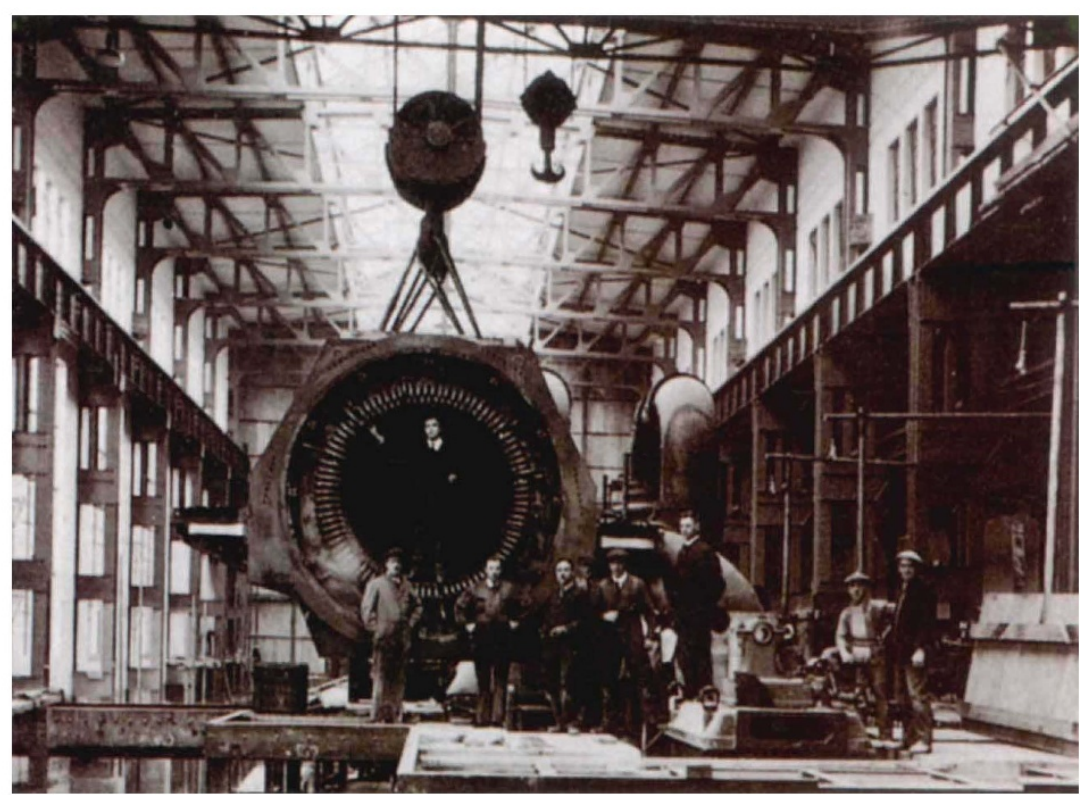

IRONBRIDGE in Shropshire, England, was at the forefront of developments in coal, iron and steam. But it was a late arrival to the brighter world of electricity. By the late 1930s however, when most of the ironworks and coalmines had closed, the region had become a focus for both the generation and distribution of electricity across Britain. This photograph shows Ironbridge "A" Power Station under construction in the years around 1930. The neighbouring "B" Station, still in operation today, was built in response to the demands of the boom years of the 1960 s. The picture is taken from Ironbridge and the Electric Revolution by Michael Stratton (John Murray, £9.99), a slender well-illustrated paperback that will appeal to all with an interest in British social, economic, industrial or architectural history.

might have been called Pigovian economics is today known as welfare economics, benefit-cost analysis, even environmental economics. And that has been popularized by many economists.

Why then has Hawken attracted such attention for repeating what others have done? First, he probably says it all more persuasively. There are a few academic references in the book: source material is mainly newspaper and other popular articles. Second, he is a businessman, and a successful one. As such he speaks for, as well as to, business. He is right to say that nothing much will change until business changes. The reality is that businessmen and women have the power to change things, and that any attempt to change the world against the "natural impulses" of human beings, as he puts it, will very probably fail. Third, but unfortunately, Hawken clearly believes in some kind of ecological collapse if things are not changed rapidly, and so he latches on to some disastrous examples of the way to go. As just one example, he believes the German 'Duales' system of recycling waste is to be applauded. The system obliges producers of packaging to take the packaging back unless they can guarantee to recycle it to target levels set by the government. Never mind that the result has been a flood of useless materials, depressing prices and encouraging waste to be dumped abroad, to the detriment of recycling schemes elsewhere. It is surprising to see this scheme lauded in the same breath as ecological taxes: they are two very different things. The Duales system is a muddled mix of eco-taxes and oldfashioned command and control, all backed up by a threat that failure to recycle will result in something worse - 'greenmail' rather than blackmail. As to ecological collapse - it could happen but it is doubtful. The likelihood is simply that of a far more unpleasant, far more insensitive, but wholly sustainable world.

But no one can doubt Hawken's sincerity. The idea of business mimicking nature, not exceeding the capacity of the Earth to absorb wastes or depleting its overall natural stocks, is appealing, if once again familiar. The sustainable business, as he puts it, engages in production processes that are "human, worthy, dignified and intrinsically satisfying". The idea of a new world trade order that rewards those who practise sustainable resource use with low or zero tariffs is also attractive. If Hawken can say all this, if he can make others believe this is a truly fresh look at business and the environment, and if he can have real influence, then all power to his environmental elbow.

David Pearce is director of the Centre for Social and Economic Research on the Global Environment, University College London, Gower Street, London WC1E 6BT, UK. 